\title{
G \& S Manufacturing: An Applied Auditing Case
}

Ellen L. Landgraf, PhD, CPA, CFE, Loyola University, USA

\begin{abstract}
This case provides students with the opportunity to gain hands on experience in the audit of cash disbursements, a voucher system and internal controls (or the lack there of) in the disbursement process. In particular, practical examples of concepts and procedures taught in an introductory auditing course, namely vouching, tracing, tests of controls and substantive testing are exemplified. The case includes sample invoices and a voucher register allowing the students to look at "actual" documents and ask good important questions. The case is broken down into three parts to allow students to receive feedback before continuing and the instructor plays the role of "consultant" providing an additional important learning opportunity. $G \& S$ Manufacturing is a small privately-held producer of steel products for the consumer market. As staff auditors performing part of the audit of $G \& S$ for the calendar year ended December 31, 2013 students will have to identify control deficiencies, substantive errors and other matters of concern in the audit of payables and cash disbursements. Students are provided with a copy of the voucher register for the month of December and all invoices relating to a selected sample of vouchers. The learning objectives of the case explicitly address the AICPA's (American Institute of Certified Public Accountants) functional competencies of risk analysis, measurement and reporting; personal competencies of problem solving and decision making, and communication; and broad business competency of strategic/critical thinking.
\end{abstract}

Keywords: Auditing Case; Directional Testing; Applied Auditing Procedures

\section{INTRODUCTION}

ou have been assigned as a staff assistant on the audit of G \& S Manufacturing Company for the year ended December 31, 2013. This firm manufactures steel products for the consumer market.

You are working on the cash disbursements section of the audit program. The in-charge auditor has asked you to perform relevant auditing procedures for this part of the audit including vouching the entries in the December voucher register numbered 162 through 184 . Your objectives are to identify any weaknesses in internal accounting control, any errors in account balances, and items which should be investigated during subsequent audit tests.

\section{BACKGROUND AND CLIENT INFORMATION}

\section{Internal Control over Accounts/Vouchers Payable and Cash Disbursements}

The client uses a voucher register. Each invoice is entered in the register when it is received. However, when applicable, the following personnel must approve the voucher prior to its payment. 


\title{
PERSON AUTHORIZED
}

APPROVAL TO APPROVE

TITLE

Quantities

Richard Carlson

Accounting department clerk

(A quantity approval is needed for physical goods-Richard, according to your notes, compares the quantities on the original purchase order to those on the receiving report and finally the invoice before initialing.)

$\underline{\text { Prices }}$

\author{
Willard Jones \\ or
}

Purchasing agents

John Colfert

(A price approval is generally needed when there are various vendors and prices for goods or services. Willard or John will compare the prices to the purchase order or contract before initialing.)

\section{Extensions}

Mary Kerrigan

Accounting department clerk

(Whenever there is a computation of quantities or quantities times price on an invoice the accuracy of that computation is verified by Mary before initialing.)

\section{Distribution}

Edward Mavis

(Ed verifies that the accounts to be charged are appropriate before initialing.)

\section{Accounting department clerk}

Each individual notes approval in the voucher stamp on the invoice by placing his/her initials next to the item for which approval is being given.

The documents which your supervisor has requested for this test have been provided by the client and consist of the December voucher register (Appendix A) and all invoices relating to voucher numbers 162 through 184 (Appendix B).

\section{REQUIREMENTS}

The in-charge auditor instructs you to perform all audit steps possible with the given information. This case consists of three assignments. The background information should be read prior to completing the first assignment. Students should also familiarize themselves with the given information (The December voucher register (Appendix A) and copies of the invoices with voucher stamps (Appendix B) as well as review the following topics in their Auditing text: vouching, tracing, voucher system, internal controls surrounding payables and cash disbursements, tests of controls, substantive testing and audit programs.

\section{Assignment 1-Proposed Audit Procedures and Setting Up a Working Paper}

The first assignment asks the student to list the proposed audit procedures to be applied to the December voucher register and the invoices provided, and to set up a working paper to note (1) Possible deviations from prescribed controls, (2) Potential substantive errors and (3) Any points which are to be followed up on. Assignment 1 should take 1-2 hours to complete. Students are told that it is necessary for them to enumerate audit procedures that can be performed with the specific information they have been given. They are also instructed that simply duplicating an audit program from the text or other sources would not be appropriate. 


\section{Learning Objectives}

Upon completing assignment \#1 students should be able to:

- $\quad$ Differentiate between tracing and vouching (directional testing)

- $\quad$ Describe and be able to identify some basic control features of a voucher system

- Articulate audit procedures relative to given information

\section{Assignment 2-Performing Audit Procedures}

The second assignment requires the student to actually perform the procedures enumerated in the first assignment and to list on a work paper the number of each voucher for which an error has been found or there is the need for additional audit work. After each number listed the student should specify the nature of (1) the deviation from the prescribed control if one or more have occurred, (2) the substantive error if appropriate and (3) any points which are to be followed up on. Assignment 2 should take 4-5 hours to complete.

\section{Learning Objectives}

Upon completing assignment \#2 students should be able to:

- Identify and describe control deficiencies associated with a voucher system

- Identify and describe misstatements (substantive errors) in source documents and the recording as well in the underlying accounting records.

- Identify other areas of concern in the examination of client provided records (think critically-out of the box.)

\section{Final Assignment}

The final assignment requires the student to reflect on their work and submit a well-developed report summarizing their findings on internal control over payables and cash disbursements at G \& S Manufacturing as well as the risk of material misstatement in the payables area of the audit. The final assignment should take 1-2 hours to complete.

\section{Learning Objectives}

Upon completing the final assignment students should be able to:

- Document, in a clear and concise manner, the results of audit tests

- $\quad$ Describe the implications of audit-test findings

\section{SKILLS AND COMPETENCIES}

This case explicitly addresses several core competencies identified and upheld as still being relevant by the American Institute of Certified Public Accountants (AICPA) in the CPA Horizons 2025 Report (AICPA, 2011). The CPA Horizons 2025 Report "leveraged insights from more than 75,000 comments from CPAs in all segments of the accounting profession, regulators, thought leaders and futurists to highlight key trends and chart what the profession will face in the years leading up to 2025" (CPA Horizons 2025: A Road Map for the Future, 2011). Among the necessary core competencies (defined as a unique combination of human skills, knowledge and technology that provides value and results to the user) featured in this case are Communications Skills (the ability to effectively exchange reliable and meaningful information, using appropriate context and interpersonal skills) and CriticalThinking and Problem-Solving Skills (the ability to evaluate facts, challenge assumptions and apply judgment to develop relevant solutions) (AICPA, 2011). In assignment \#2 of this case, students are required to identify control deficiencies and dollar misstatements as well as other audit issues and risks. This identification process allows students to gain an appreciation for critical thinking in an auditing context. 
The utilization of cases in auditing is an excellent vehicle to impart the core competencies outlined in the CPA Horizons 2025 Report. The accounting literature supports the benefits of utilizing cases in the teaching of accounting. Stout (1996) indicated that students found the case analysis section of the cost accounting course to be interesting and important albeit difficult. Specific benefits derived from the utilization of cases in accounting education with regard to imparting including critical-thinking, problem-solving, and analytical skills were also cited by Knapp and Knapp (2000).

\section{TEACHING NOTES}

\section{General Issues}

The case should be integrated appropriately into the course. Discussions/lectures on directional testing, internal control and tests of controls, substantive testing and misstatements, audit programs as well as the audit of cash and payables (a voucher system) should precede the assignment of this case. Therefore it should probably fall into the second half of the course or even be utilized as a final project. Furthermore, the case should be a significant portion of grade (15-20\%). This sends a message to the student as to the importance of the assignment.

The case can be assigned as an individual project or to teams of up to 4 students. In previous class tests, it was stated that students may choose to do the assignment individually or as a group project with no more than 4 members in the group and were told to choose carefully because only one group grade will be assigned thus letting them deal with the "free-rider" problem. In the most recent class testing (Fall of 2014) students were required to submit individually.

Separate due dates for the assignments provide for continuous monitoring or feedback to the students. The use of a single due date is also an option. The assignment is to be typed and not e-mailed. A $50 \%$ penalty was assessed if the assignments were not typed and a $10 \%$ penalty per hour assessed for a late assignment.

Finally, the instructor acted as a consultant (or senior on the job) for certain class periods (which were stipulated in advance) to answer questions regarding the assignments. No other questions via phone, office visit or email regarding this assignment would be answered by the instructor. This encouraged attendance and participation.

\section{Student Feedback and Case Effectiveness}

The case has been used in a multiple sections of an introductory auditing course at a private university. Most recently twenty-two undergraduate students in a writing-intensive section of Auditing completed evaluations of the case in the Fall Semester of 2014. Students were given a short anonymous survey immediately after turning in their case (ensuring high participation rates). Students were asked the questions found in Table 1. Each question response was on a 1-10 scale with 10 being "most helpful". Table 1 also summarizes the students' responses.

Table 1. Student feedback - Summary of students' responses (Part 1)

\begin{tabular}{|c|c|c|}
\hline Assessment Question & Mean & $\begin{array}{l}\text { Standard } \\
\text { Deviation }\end{array}$ \\
\hline How helpful was the case in understanding directional testing (tracing and vouching?) & 8.40 & 1.18 \\
\hline $\begin{array}{l}\text { How helpful was the case in understanding the importance of internal control procedures } \\
\text { related to accounts/vouchers payable? }\end{array}$ & 8.59 & 1.43 \\
\hline $\begin{array}{l}\text { How helpful was the case in enhancing your critical thinking, analytic and } \\
\text { communication skills as related to audit procedures? }\end{array}$ & 8.40 & 1.46 \\
\hline $\begin{array}{l}\text { How helpful was the case in understanding basic spreadsheet functions as they relate to } \\
\text { accounting? }\end{array}$ & 6.77 & 2.44 \\
\hline $\begin{array}{l}\text { How helpful was the case in making you more comfortable reading and interpreting } \\
\text { client prepared documents? }\end{array}$ & 7.63 & 1.83 \\
\hline $\begin{array}{l}\text { How helpful was the case in helping you understand expense allocation issues related to } \\
\text { accounts/vouchers payable? }\end{array}$ & 7.72 & 1.51 \\
\hline
\end{tabular}


The assessment questions were in general organized around the previously stated Learning Objectives for the assignments as well as measuring the students' incremental learning as to spreadsheets/worksheets and client records provided by the working through of this case. The scores relative to learning objectives ranging from 7.728.59 indicate that students found the case helpful in understanding directional testing, internal control over accounts/vouchers payable, audit procedures and expense allocation. The lowest score, 6.77 indicates perhaps that students may already have a good grasp of spreadsheet functions by the time they reach the auditing course. The assessment also indicates that students felt that the case made them feel more comfortable reading and interpreting client prepared documents as indicated by the 7.63 mean. Additionally, students were asked two questions regarding the amount of time it took them to prepare for and complete the case. Students' responses are summarized in Table 2.

Table 2. Student feedback - Summary of students' responses (Part 2)

\begin{tabular}{|l|c|c|c|}
\hline \multicolumn{1}{|c|}{ Question } & Average & $\begin{array}{c}\text { Standard } \\
\text { Deviation }\end{array}$ & $\begin{array}{c}\text { Range } \\
\text { Minimum to } \\
\text { Maximum Time }\end{array}$ \\
\hline $\begin{array}{l}\text { How much time did you spend on preparing for the initial case } \\
\text { discussion in class? }\end{array}$ & $.54 \mathrm{hrs}$ & $.75 \mathrm{hrs}$ & 0 to $3 \mathrm{hrs}$ \\
$\begin{array}{l}\text { How much additional time did you spend analyzing and } \\
\text { completing the case? }\end{array}$ & $6.52 \mathrm{hrs}$ & $6.47 \mathrm{hrs}$ & 2 to $32 \mathrm{hrs}$ \\
\hline
\end{tabular}

The answers to the above questions indicate that 1) Undergraduate students do not necessarily spend a great deal of time in preparation for an assignment even though they are instructed to do so and 2) The approximate completion times for the assignments were born out (although there was a large range in terms of additional time spent on completing the case).

\section{SUGGESTED SOLUTIONS}

\section{Assignment 1}

Suggested Audit Procedures

1. Scan voucher register for unusual items

2. Foot and cross-foot voucher register

3. Trace invoices and vouchers numbered 162-184 to the voucher register

4. Vouch amounts recorded in the voucher register to information on the voucher and invoice

5. Inspect information on each voucher

a. Note approvals

b. Recalculate extensions

c. Verify distribution

6. Note any control errors or substantive errors on the worksheet

7. Examine evidence of cancelled vouchers when paid

\section{Assignment 2 and Final Assignment}

What follows are some general guides as to errors found in the case, which may have been included on the worksheet and/or Final Report. 
In analyzing the Voucher Register (which is a client-prepared document) the following potential issues/questions should be raised (related assertions are in parenthesis):

- Why is there Voucher \# 148A? (completeness)

- Where is Voucher \#170? (completeness)

- The voucher register does not foot/cross foot, specifically the total Manufacturing Expenses for the month should be $\$ 16,214.32$ (not $\$ 18,214.32$ ) and the total for other accounts should be $\$ 44,005.20$ (not $53,005.20)$ (accuracy/valuation)

- Why on voucher 159 are building Repairs of $\$ 842$ charged to Manufacturing?

In analyzing the Invoices and Voucher Stamps the following potential issues/questions should be raised:

- $\quad$ None of the vouchers were marked paid

- $\quad$ Month end payroll accruals are needed

- How is insurance handled? Other Prepaids?

- What kind of documentation is required for approval of such items as petty cash reimbursement, payroll, related party transactions, and internal vouchers? 


\begin{tabular}{|c|c|c|c|}
\hline \multicolumn{4}{|c|}{ Worksheet Solution-Invoices and Vouchers } \\
\hline Voucher \# & $\begin{array}{c}\text { Deviation from Prescribed } \\
\text { Control } \\
\end{array}$ & Substantive Errors & Other \\
\hline 162 & $\begin{array}{l}\text { No approval for extension or } \\
\text { distribution }\end{array}$ & & $\begin{array}{l}\text { Why allocation to Power and } \\
\text { Office Expense? What basis used? }\end{array}$ \\
\hline 163 & & $\begin{array}{l}\text { Charge to FIT-the city does not } \\
\text { collect federal taxes }\end{array}$ & $\begin{array}{l}\text { Where should the charge go to? } \\
\text { Very suspicious... }\end{array}$ \\
\hline 164 & & $\begin{array}{l}\text { Depends on whether Advertising } \\
\text { is an expense or prepaid }\end{array}$ & $\begin{array}{l}\text { See a clip of the ad-was it } \\
\text { advertising expense or prepaid? }\end{array}$ \\
\hline 165 & No approval for extension & & $\begin{array}{l}\text { This is a November expense-was it } \\
\text { booked as a payable Nov. } 30 ? \\
\text { What about payable } 12 / 31 ?\end{array}$ \\
\hline 166 & & $\begin{array}{l}\text { Was this for raw materials or } \\
\text { supplies? }\end{array}$ & $\begin{array}{l}\text { What was lumber used for-they } \\
\text { make steel construction products? }\end{array}$ \\
\hline 167 & Wrong person on quantity & $\begin{array}{l}\text { Is this a capital expenditure } \\
\text { (Office furniture) or expense? }\end{array}$ & $\begin{array}{l}\text { Why shipped to different address? } \\
\text { Suspicious... }\end{array}$ \\
\hline 168 & & & $\begin{array}{l}\text { Is distribution ok? Is this all the } \\
\text { approval needed for payroll? }\end{array}$ \\
\hline 169 & $\begin{array}{l}\text { Why did MK initial extension (1 } \\
\text { Fork Lift Tractor) }\end{array}$ & & Paid late \\
\hline 170 & & & Where is it? \\
\hline 171 & Price approval missing & Is this freight or machine? & $\begin{array}{l}\text { Appears that this is the freight on } \\
\text { perhaps a milling machine that } \\
\text { seems to be missing? Voucher } \\
170 \text { ? }\end{array}$ \\
\hline 172 & $\begin{array}{l}\text { Why did MK initial extension (1 } \\
\text { Lathe) }\end{array}$ & $\begin{array}{l}\text { Charged to Raw Materials in the } \\
\text { voucher register (should be } \\
\text { Machinery per EM) }\end{array}$ & $\begin{array}{l}\text { Paid late-did not take advantage of } \\
\text { discount }\end{array}$ \\
\hline 173 & & & $\begin{array}{l}\text { Strange account-is this a mfg. } \\
\text { expense? Probably yes-towels in } \\
\text { the restroom. Paid late. Should } \\
\text { there be a year-end accrual? }\end{array}$ \\
\hline 174 & Who is MJ on prices? & $\begin{array}{l}\text { Distribution backwards in voucher } \\
\text { register }\end{array}$ & Paid late \\
\hline 176 & $\begin{array}{l}\text { Weak control if this is all that is } \\
\text { needed for approval of an advance }\end{array}$ & $\begin{array}{l}\text { Should be charged to employee } \\
\text { advances }\end{array}$ & Who is George Olson? \\
\hline 177 & $\begin{array}{l}\text { What does MK's initialing of petty } \\
\text { cash extensions mean? } \\
\text { Price approval missing. }\end{array}$ & & Inquire as to petty cash procedures \\
\hline 178 & $\begin{array}{l}\text { MK initialed extensions and it is } \\
\text { incorrect. }\end{array}$ & $\begin{array}{l}\$ 495 \text { should be } \$ 475 \text { and cut-off } \\
\text { error }\end{array}$ & $\begin{array}{l}\text { Received } 1 / 3 \text {-is it ours in } \\
\text { December? No, FOB Destination }\end{array}$ \\
\hline 179 & $\begin{array}{l}\text { No price approval } \\
\text { Were there extensions on the } \\
\text { freight bills? }\end{array}$ & & What was it for? \\
\hline 180 & & $\begin{array}{l}\text { Distribution/accounts charged do } \\
\text { not match voucher register }\end{array}$ & \\
\hline 181 & $\begin{array}{l}\text { No approval on distribution-looks } \\
\text { like someone besides Ed did it }\end{array}$ & Should be prepaid rent & $\begin{array}{l}\text { Rent on what? Who is Arthur } \\
\text { Holmes? }\end{array}$ \\
\hline 183 & & $\begin{array}{l}\text { Possible cut-off error-check } \\
\text { shipping terms }\end{array}$ & $\operatorname{Rec} 1 / 3$-was it ours at $12 / 31$ ? \\
\hline 184 & Mk initialed an incorrect extension & Substantive error of $\$ 400$ & $\begin{array}{l}\text { Did price go down? See Voucher } \\
\# 178 \text {-did they find a cheaper } \\
\text { supplier? }\end{array}$ \\
\hline
\end{tabular}




\section{AUTHOR INFORMATION}

Ellen L. Landgraf holds a Ph.D. from the University of Illinois at Chicago, an MBA from Northern Illinois University and a BBA from Loyola University Chicago. She is a registered Certified Public Accountant (Illinois) and a CFE (Certified Fraud Examiner) Dr. Landgraf's work experience includes positions at the IRS and in public accounting (both Big Eight and small practitioner) prior to her over thirty years in academia. Her research interests are in the areas of accounting education, fraud and forensic accounting and ethics and accounting.

\section{REFERENCES}

American Institute of Certified Public Accountants (AICPA) (2011). CPA Horizons 2025 Report. New York, NY: AICPA.

American Institute of Certified Public Accountants (AICPA) (2011). CPA Horizons 2025: A Road Map for the Future. Journal of Accountancy, December, 44-47.

Knapp, M. \& Knapp, C. (2000). Perry Drug Stores, Inc.: Accounting and control issues for inventory in a retail environment. Issues in Accounting Education, 15, 237-255.

Stout, D. (1996). Experimental Evidence and Recommendations regarding Case-Based Teaching in Undergraduate Cost Accounting. Journal of Accounting Education, 14, 293-317. 
APPENDIX A - The Voucher Register

\begin{tabular}{|c|c|c|c|c|c|c|c|c|c|c|}
\hline \multicolumn{11}{|c|}{ G \& S Manufacturing } \\
\hline \multicolumn{11}{|c|}{ VOUCHER REGISTER } \\
\hline \multicolumn{11}{|c|}{ DECEMBER , 2013} \\
\hline & & & & & & \multicolumn{2}{|c|}{ MANUFACTURING EXPENSES } & & \multicolumn{2}{|l|}{ OTHER } \\
\hline \multirow[t]{2}{*}{ DATE } & VENDOR & DATE PAID & VOUCHER\# & VOUCHER & RAW & DIRECT & & & & \\
\hline & & & & PAYABLE CR & MATERIALS & LABOR & ACCOUNT & AMOUNT & ACCOUNT & AMOUNT \\
\hline $12 / 2 / 2013$ & 3 SAMPSON MANUFACTURING & $12 / 10 / 2013$ & 142 & 497.04 & $\$ \quad 497.04$ & & & & & \\
\hline $12 / 2 / 2013$ & 3 ARTHUR HOLMES & $12 / 2 / 2013$ & 143 & 250.00 & & & RENT & $\$ 250.00$ & & \\
\hline $12 / 2 / 2013$ & 3 METROPOLITAN TELEPHONE & $12 / 16 / 2013$ & 144 & 62.00 & & & & & TELEPHONE & $\$ 62.00$ \\
\hline $12 / 2 / 2013$ & 3 STEELHOUSE SUPPLY & $12 / 9 / 2012$ & 145 & $1,740.00$ & $1,740.00$ & & & & & \\
\hline $12 / 3 / 2013$ & 3 HODBERG AUTO AND TRUCK & $12 / 5 / 2013$ & 146 & $1,600.00$ & & & & & TRUCKS & $1,600.00$ \\
\hline $12 / 3 / 2013$ & 3 PENNSYLVANIA RAILROAD & $12 / 4 / 2013$ & 147 & 102.00 & & & FREIGHT-IN & 102.00 & & \\
\hline $12 / 3 / 2013$ & 3 GEORGE OLSON & $12 / 3 / 2013$ & 148 & 750.00 & & & & & COMMISSIONS & 750.00 \\
\hline $12 / 4 / 2013$ & 3 CARTWELL MANUFACTURING & $12 / 12 / 2013$ & $148 \mathrm{~A}$ & 816.00 & 816.00 & & & & & \\
\hline $12 / 4 / 2013$ & 3 PAYROLL-PLANT & $12 / 4 / 2013$ & 149 & $16,311.00$ & & $\$ 10,789.00$ & INDIRECT LABOR & $\$ 5,522.00$ & & \\
\hline $12 / 5 / 2013$ & 3 AUBRY MFG. CO. & $12 / 13 / 2013$ & 150 & $1,620.10$ & $1,620.10$ & & & & & \\
\hline $12 / 5 / 2013$ & 3 WALFORD MACHINERY & $12 / 13 / 2013$ & 151 & $19,000.00$ & & & & & MACHINERY & $19,000.00$ \\
\hline $12 / 6 / 2013$ & 3 MCKNIGHT AGENCY & $12 / 6 / 2013$ & 152 & 300.00 & & & & & INSURANCE EXPENSE & 300.00 \\
\hline $12 / 6 / 2013$ & 3 ANDRE STEEL CO & $12 / 9 / 2013$ & 153 & $2,000.00$ & & & & & BUILDING & $2,000.00$ \\
\hline $12 / 9 / 2013$ & 3 U.S. TRUCKING CORP. & $12 / 9 / 2013$ & 154 & 96.00 & 96.00 & & & & & \\
\hline $12 / 9 / 2013$ & 3 FREDERICK MFG. CO. & $12 / 17 / 2013$ & 155 & $1,466.64$ & $1,466.64$ & & & & & \\
\hline $12 / 9 / 2013$ & 3 GLENN DAVIDSON & $12 / 9 / 2013$ & 156 & 180.00 & & & & & SELLING EXPENSE & 180.00 \\
\hline $12 / 10 / 2013$ & 3 ARCHER COAL CO. & $12 / 18 / 2013$ & 157 & 500.00 & & & FUEL & 500.00 & & \\
\hline $12 / 10 / 2013$ & 3 BROOKS SUPPLY CO. & $12 / 17 / 2013$ & 158 & 200.00 & 200.00 & & & & & \\
\hline $12 / 11 / 2013$ & 3 JENNINGS \& JOHNSON & $12 / 19 / 2013$ & 159 & 842.00 & & & BUILDING REPAIRS & 842.00 & & \\
\hline $12 / 11 / 2013$ & 3 GLENWAY TRUCKING & $12 / 11 / 2013$ & 160 & 202.00 & & & FREIGHT-IN & 202.00 & & \\
\hline $12 / 12 / 2013$ & 3 JONES AUTO SALES CO. & $12 / 20 / 2013$ & 161 & $2,400.00$ & & & & & AUTO & $2,400.00$ \\
\hline $12 / 12 / 2013$ & 3 EDISON ELECTRIC & $12 / 20 / 2013$ & 162 & 872.20 & & & POWER & 800.00 & 0 OFFICE EXPENSE & 72.20 \\
\hline $12 / 13 / 2013$ & 3 CITY OF CHICAGO & $12 / 16 / 2013$ & 163 & $4,500.00$ & & & & & TAXES & $4,500.00$ \\
\hline $12 / 13 / 2013$ & 3 HUGHES ADVERTISING & $12 / 23 / 2013$ & 164 & $1,150.00$ & & & & & ADVERTISING & $1,150.00$ \\
\hline $12 / 16 / 2013$ & 3 METROPOLITAN TELEPHONE & $12 / 30 / 2013$ & 165 & 62.00 & & & & & TELEPHONE & 62.00 \\
\hline $12 / 17 / 2013$ & 3 LOCAL LUMBER & $12 / 17 / 2013$ & 166 & 600.00 & & & SUPPLIES & 600.00 & & \\
\hline $12 / 17 / 2013$ & 3 WELLS FURNITURE & $12 / 17 / 2013$ & 167 & 750.00 & & & & & OFFICE EXPENSE & 750.00 \\
\hline $12 / 18 / 2013$ & 3 PAYROLL-PLANT & $12 / 18 / 2013$ & 168 & $17,002.00$ & & $11,220.00$ & INDIRECT LABOR & $5,782.00$ & & \\
\hline $12 / 18 / 2013$ & 3 TROWNE EQUIPMENT & $1 / 2 / 2014$ & 169 & $2,150.00$ & & & & & MACHINERY & $2,150.00$ \\
\hline $12 / 19 / 2013$ & 3 AMERICAN CARTAGE & $12 / 20 / 2013$ & 171 & 490.00 & & & FREIGHT-IN & 490.00 & & \\
\hline $12 / 19 / 2013$ & 3 LAUREL MANUFACTURING CO. & $1 / 2 / 2014$ & 172 & $5,200.00$ & $5,200.00$ & & & & & \\
\hline $12 / 20 / 2013$ & 3 LAUNDRY SUPPLY COMPANY & $1 / 2 / 2014$ & 173 & 47.00 & & & EMPLOYEE SERVICE & 47.00 & & \\
\hline \multirow[t]{2}{*}{$12 / 23 / 2013$} & 3 OFFSET PRINTING CO. & $1 / 6 / 2014$ & 174 & $1,500.00$ & & & & & ADVERTISING & $1,000.00$ \\
\hline & & & & & & & & & OFFICE EXPENSE & 500.00 \\
\hline $12 / 26 / 2013$ & 3 UNITED STATES CASTING & $1 / 24 / 2014$ & 175 & $1,562.22$ & $1,562.22$ & & & & & \\
\hline $12 / 27 / 2013$ & 3 GEORGE OLSON & $12 / 27 / 2013$ & 176 & 140.00 & & & & & ACCOUNTS RECEIVABLE & 140.00 \\
\hline \multirow[t]{3}{*}{$12 / 30 / 2013$} & 3 JOHN WATKINS, PETTY CASH & $12 / 30 / 2013$ & 177 & 189.00 & & & & & GENERAL & 42.00 \\
\hline & & & & & & & & & OFFICE & 82.00 \\
\hline & & & & & & & & & SELLING & 65.00 \\
\hline $12 / 30 / 2013$ & 3 ALDRICH \& JONES & $1 / 7 / 2014$ & 178 & $1,225.00$ & $1,225.00$ & & & & & \\
\hline $12 / 30 / 2013$ & 3 FAST FREIGHT & $12 / 30 / 2013$ & 179 & 27.32 & & & FREIGHT-IN & 27.32 & & \\
\hline $12 / 30 / 2013$ & 3 EXECUTIVE PAYROLL & $12 / 30 / 2013$ & 180 & $8,000.00$ & & & SUPERINTENDENT & 800.00 & O ADMINISTRATIVE & $7,200.00$ \\
\hline $12 / 30 / 2013$ & 3 ARTHUR HOLMES & $12 / 30 / 2013$ & 181 & 250.00 & & & RENT & 250.00 & & \\
\hline $12 / 31 / 2013$ & 3 HEILPERN IRON WORKS & $1 / 9 / 2014$ & 182 & 600.00 & 600.00 & & & & & \\
\hline $12 / 31 / 2013$ & 3 CARTWELL MANUFACTURING & $1 / 30 / 2014$ & 183 & $1,356.00$ & $1,356.00$ & & & & & \\
\hline \multirow[t]{2}{*}{$12 / 31 / 2013$} & 3 JOHNSON SUPPLY & $1 / 9 / 2014$ & 184 & $\underline{4,320.00}$ & $\underline{4,320.00}$ & & & & & \\
\hline & & & & $\$ 102,927.52$ & $\underline{\$ 20,699.00}$ & $\underline{\underline{\$ 22,009.00}}$ & & $\$ 18,214.32$ & & $\$ 53,005.20$ \\
\hline
\end{tabular}




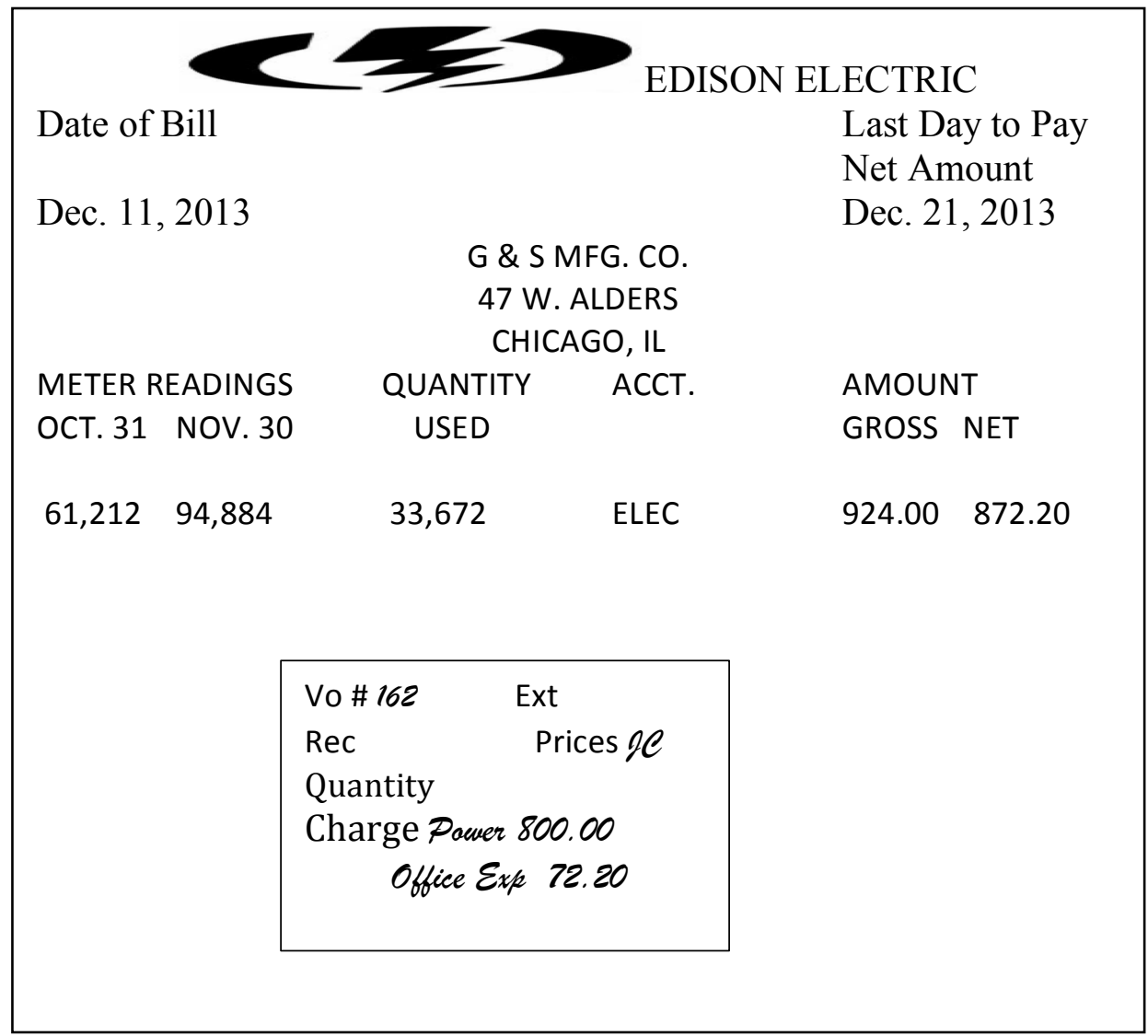

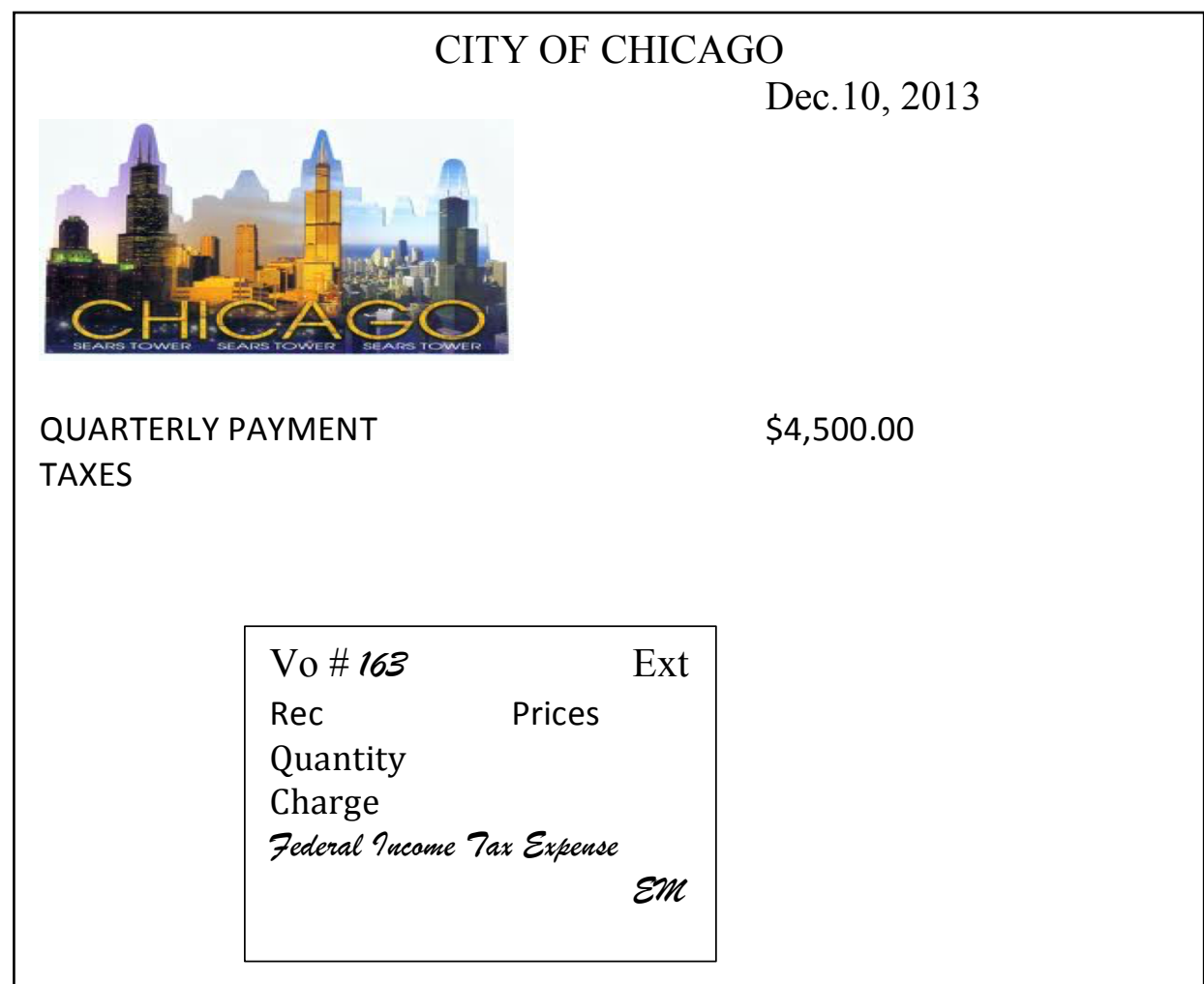




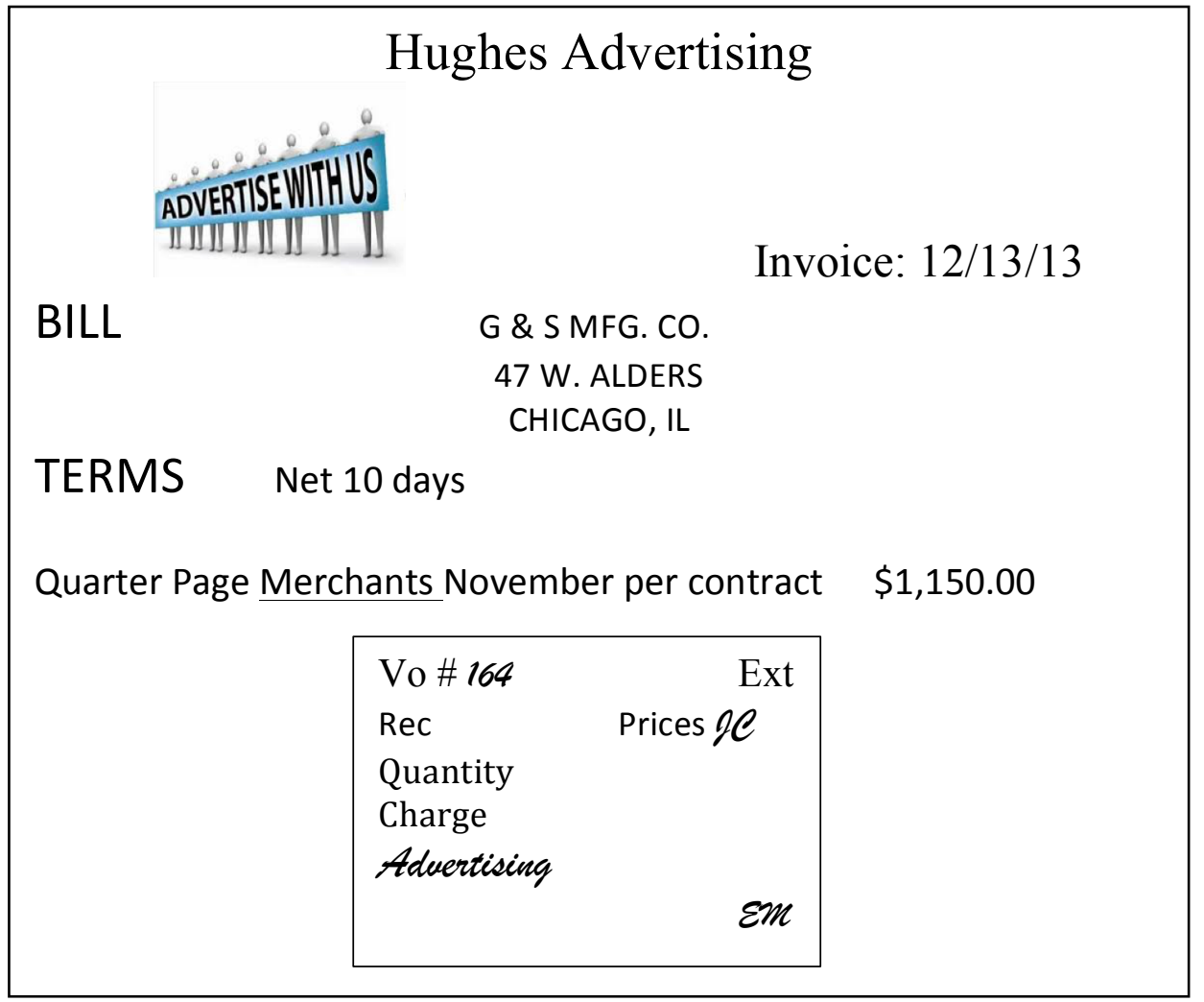

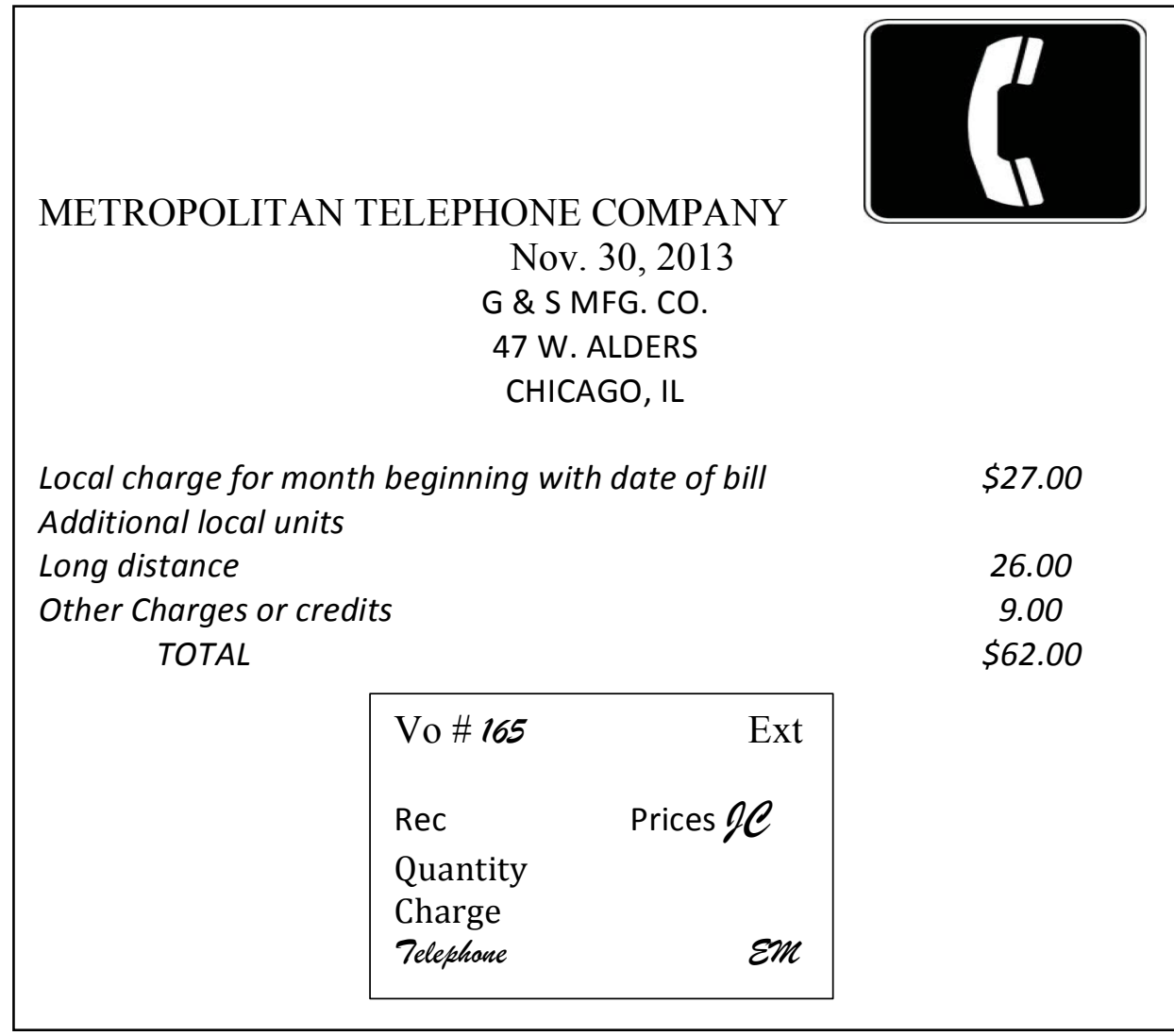




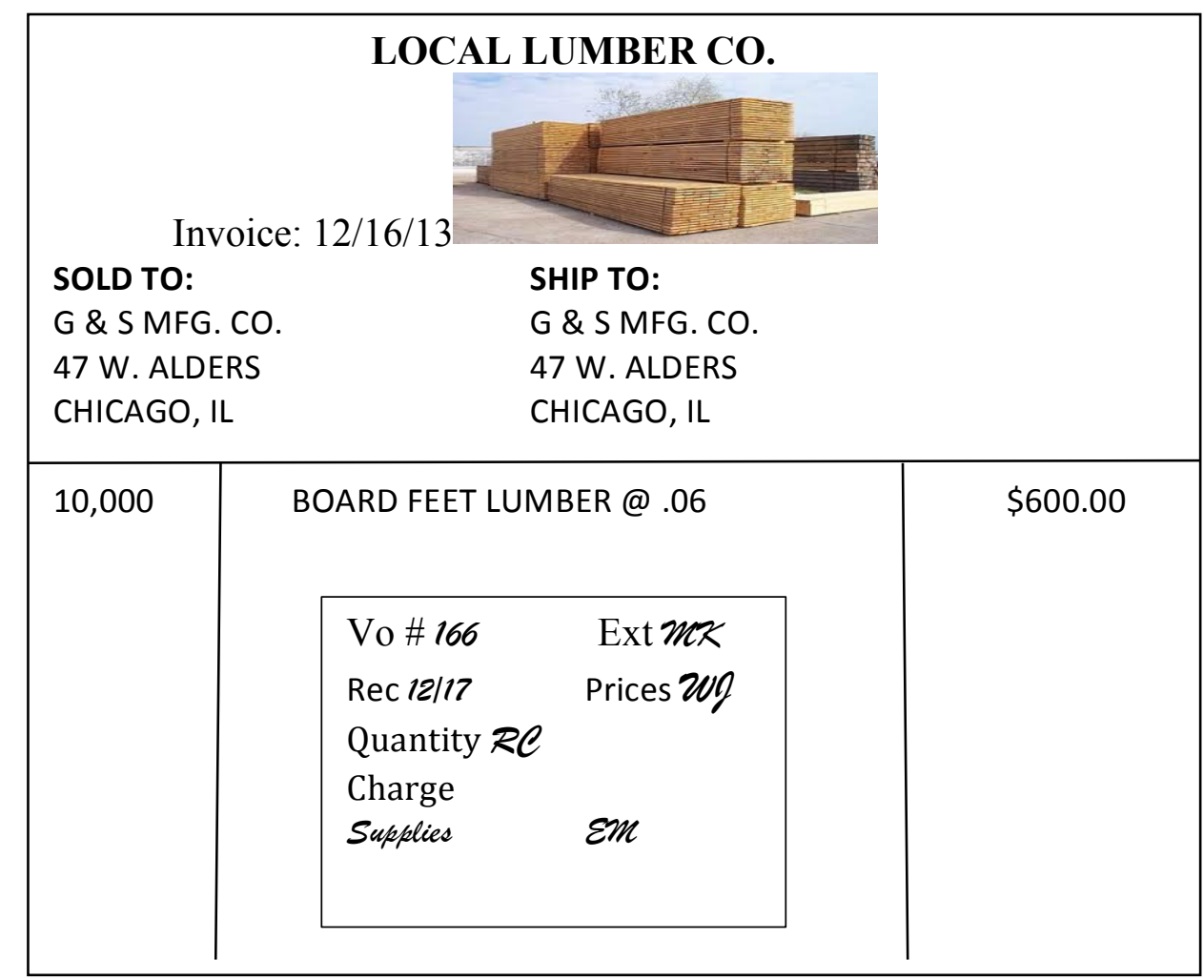

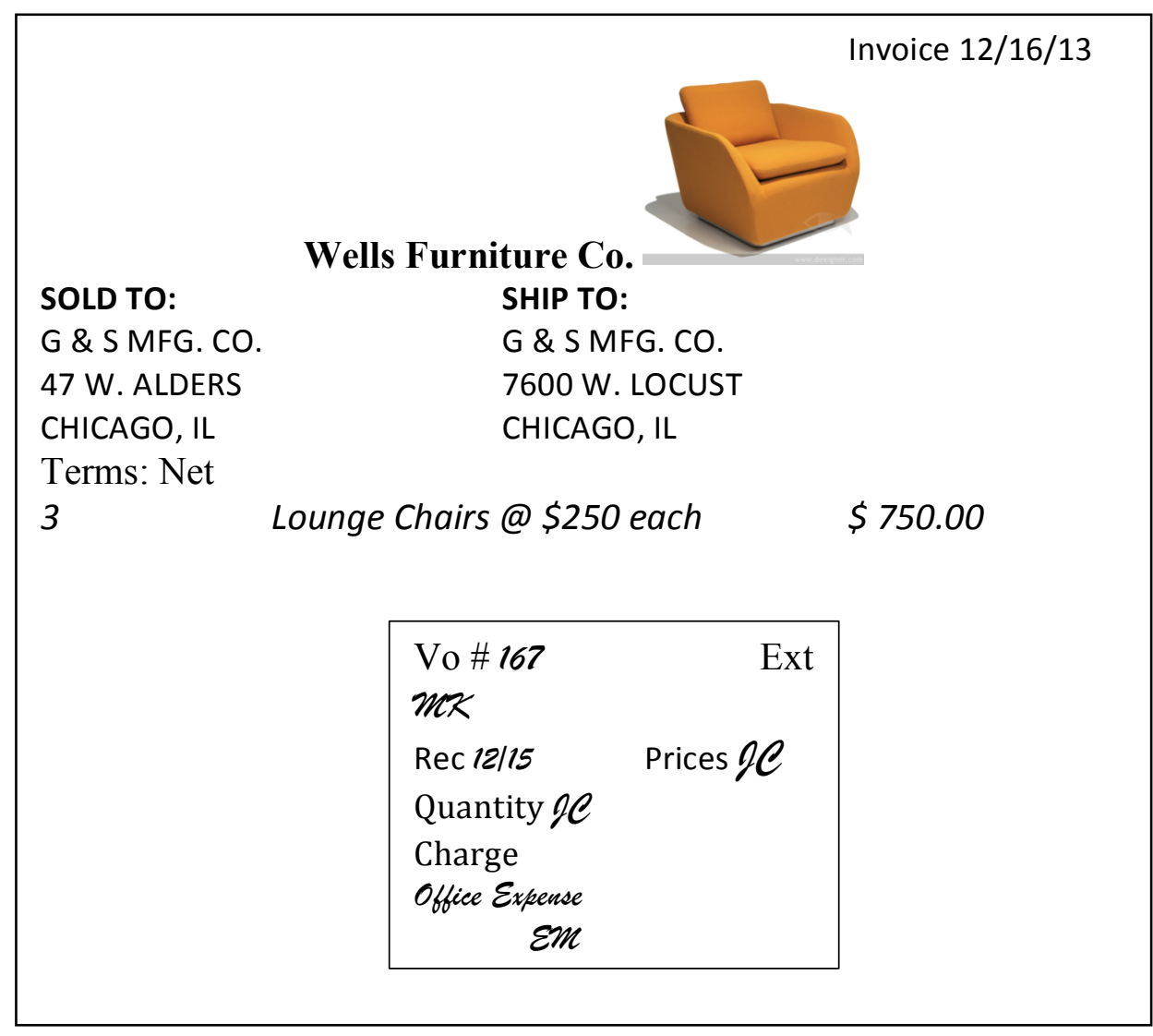




\section{INTERNAL VOUCHER}

G \& S MFG. CO.

47 W. ALDERS

CHICAGO, IL

PAYMENT MADE TO

$12 / 18 / 13$

AMOUNT

Plant Payroll

Two weeks ending 12/15

$\$ 17,002.00$

\begin{tabular}{|c|c|}
\hline \multicolumn{2}{|l|}{ Vo \# 168} \\
\hline $\operatorname{Rec}$ & Prices \\
\hline Quantity & \\
\hline Charge & \\
\hline Direct Labar & 11.220 \\
\hline Indirect Labar & 5.782 \\
\hline & $\varepsilon m$ \\
\hline
\end{tabular}

Invoice $12 / 17 / 13$

SOLD TO:

G \& S MFG. CO.

47 W. ALDERS

CHICAGO, IL

\section{Trowne Equipment} SHIP TO:

G \& S MFG. CO.

$47 \mathrm{~W}$. ALDERS

CHICAGO, IL

Terms: Net 15 DAYS, FOB S.P.

1

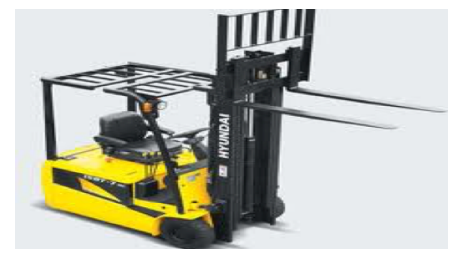

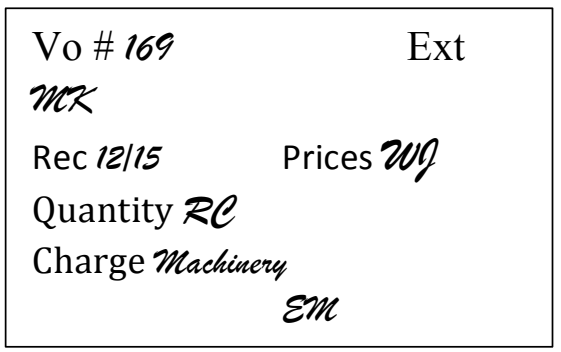



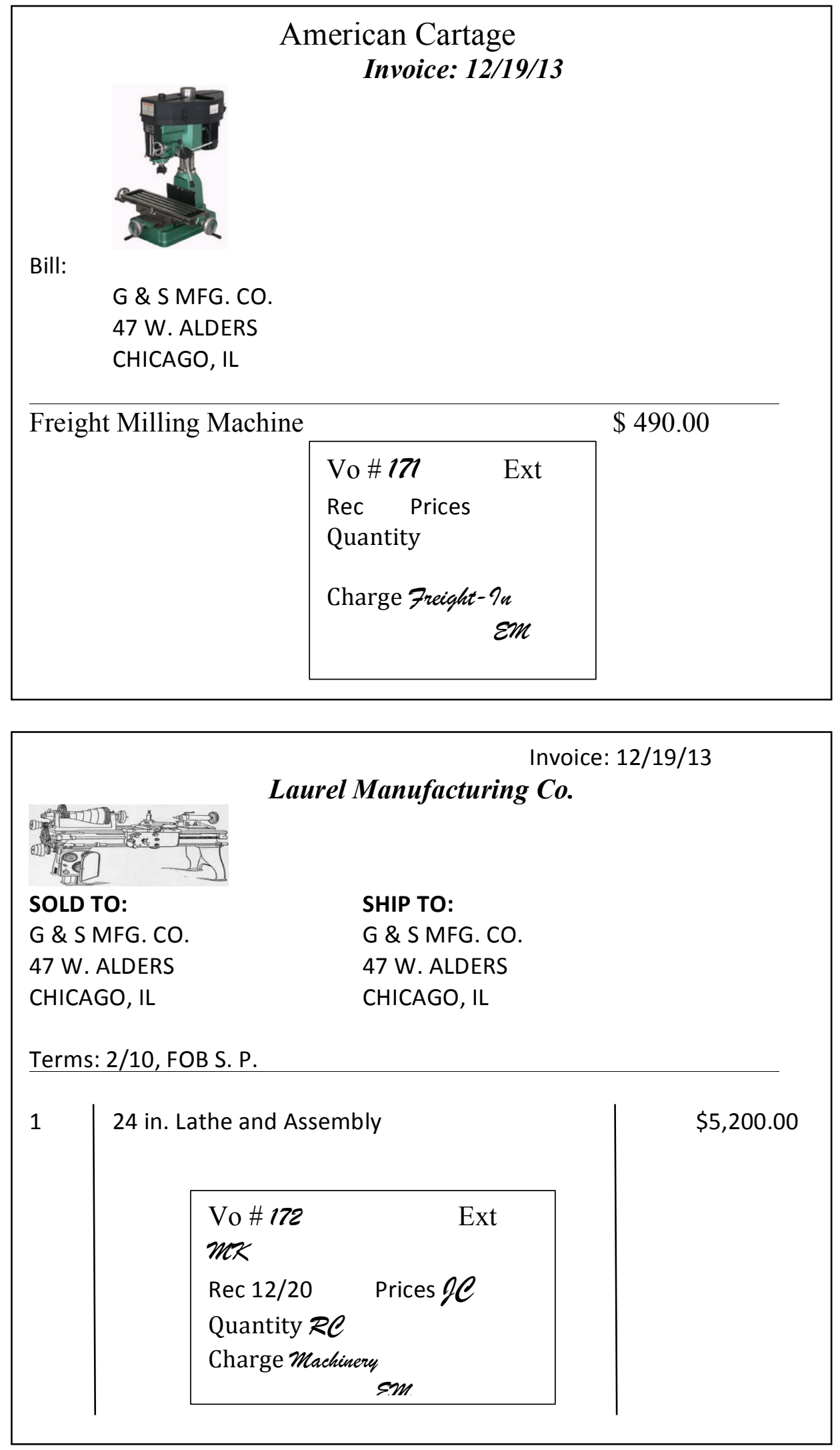
Invoice: $12 / 18 / 13$

Laundry Supply Co.

SOLD TO:

G \& S MFG. CO.

$47 \mathrm{~W}$. ALDERS

CHICAGO, IL

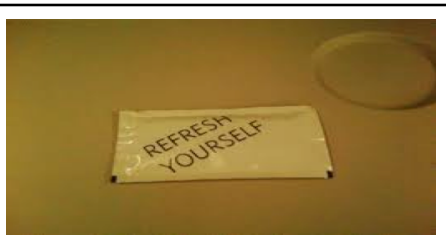

SHIP TO:

G \& S MFG. CO.

47 W. ALDERS

CHICAGO, IL

Terms: $2 / 10$

Towel Service

November 15 to December 15

\begin{tabular}{l} 
Vo \#173 $\quad$ Ext \\
Rec \\
Quantity \\
Charge Employee Service \\
\multicolumn{2}{c}{ Em }
\end{tabular}

SOLD TO:

G \& S MFG. CO.

$47 \mathrm{~W}$. ALDERS

CHICAGO, IL
Invoice: 12/20/13

\section{Offset Printing Co.}

SHIP TO:

G \& S MFG. CO.

47 W. ALDERS

CHICAGO, IL

Terms: $2 / 10$

1000 EACH Catalogs @ \$500 per M

100 rms. Letterhead @ \$10 per ream

$$
\text { Vo \# } 174
$$$$
\text { ma }
$$

$\operatorname{Rec} 12 / 23$

Quantity RC

Charge Aduertising

Office Expense
$\$ 500$

1,000

$\$ 1,500$ 


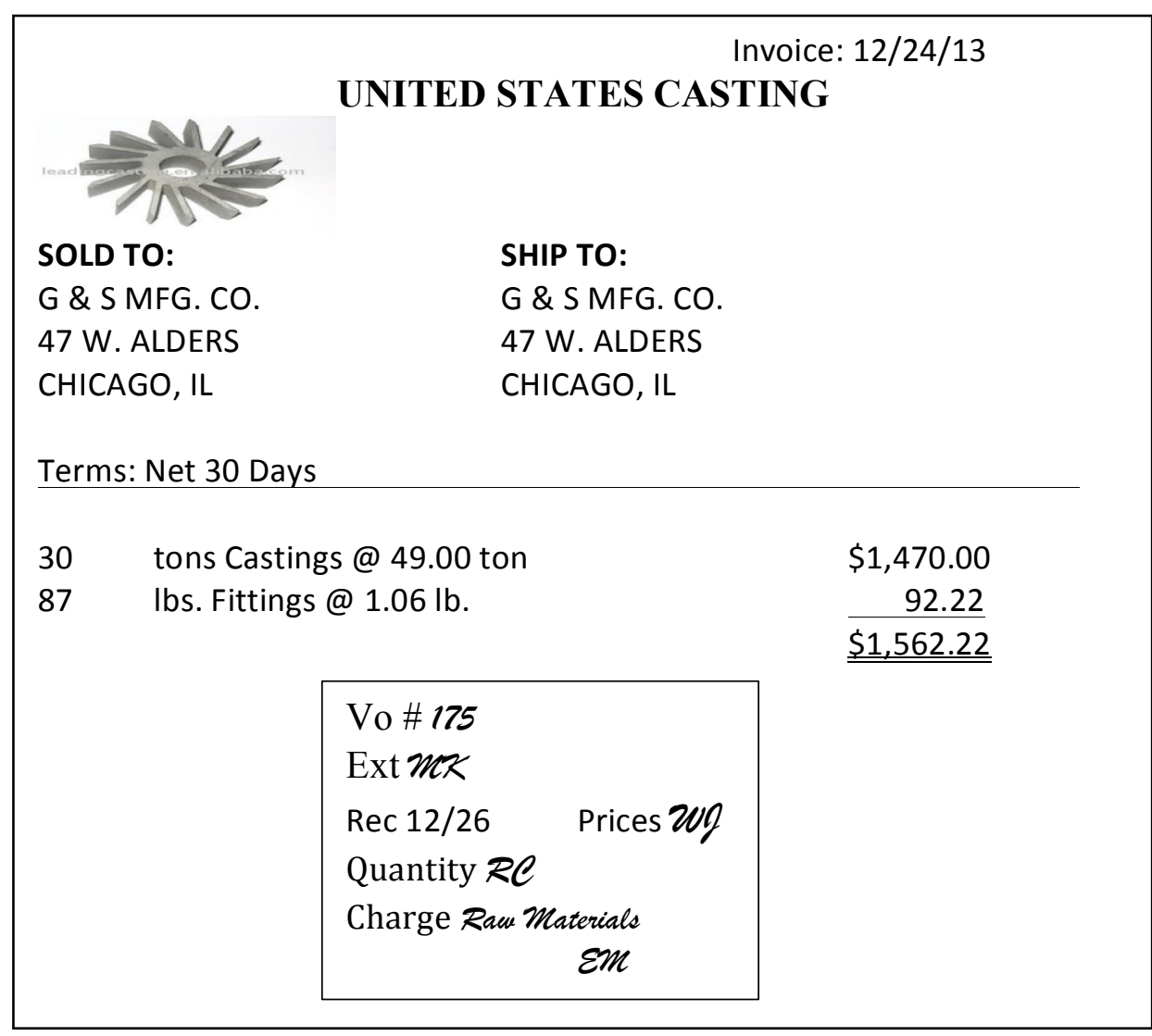

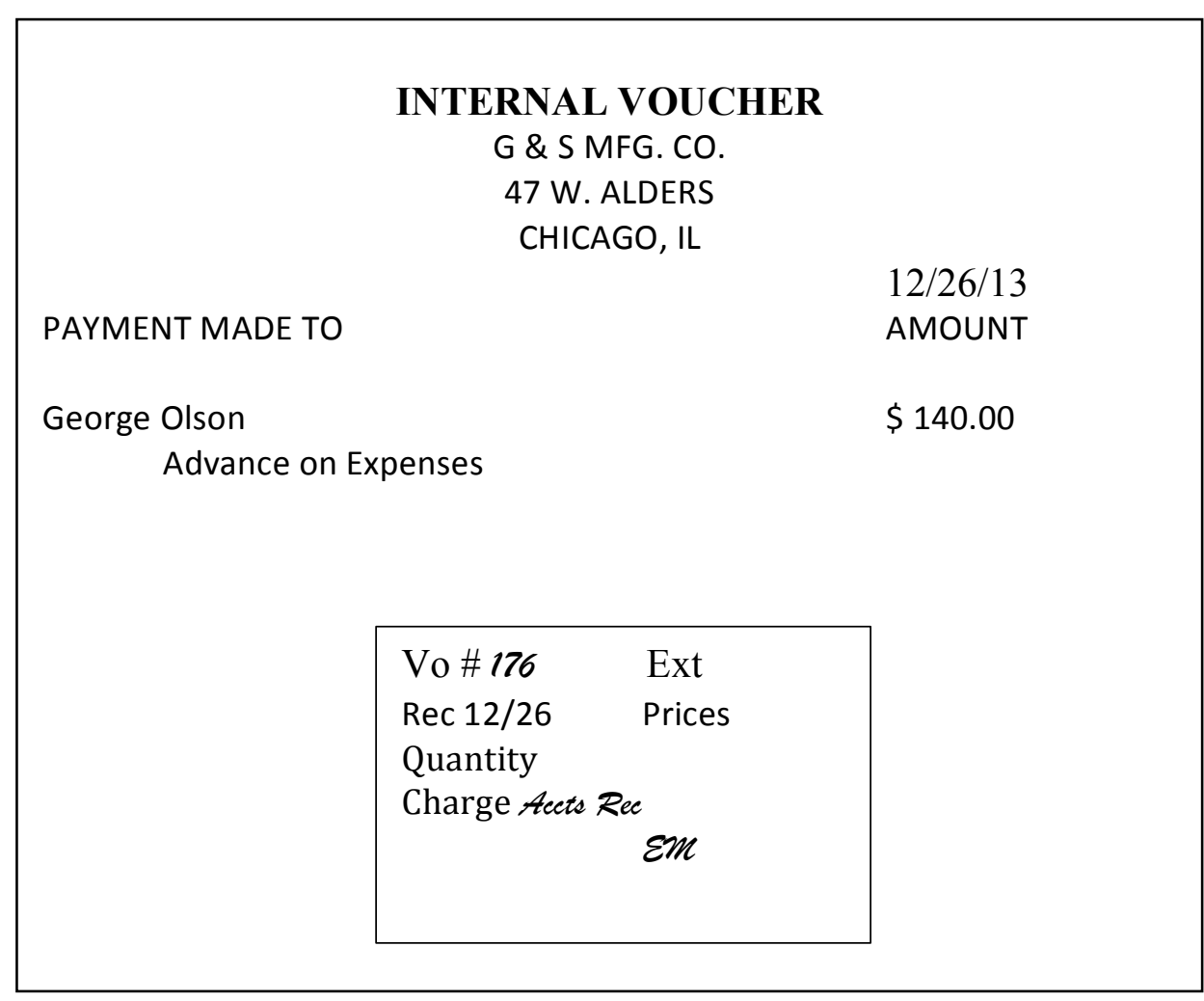




\section{INTERNAL VOUCHER}

G \& S MFG. CO.

47 W. ALDERS

CHICAGO, IL

\section{PAYMENT MADE TO}

John Watkins, Petty Cash

To reimburse petty cash per attached vouchers
$12 / 30 / 13$

AMOUNT

$\$ 189.00$

\section{ALDRICH AND JONES}

Invoice: $12 / 27 / 13$

SOLD TO:

G \& S MFG. CO.

47 W. ALDERS

CHICAGO, IL

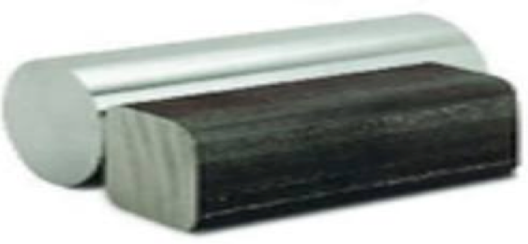

SHIP TO:

G \& S MFG. CO.

47 W. ALDERS

CHICAGO, IL

Terms: Net 10 days FOB destination

10 tons Rerolling Billets @ \$73.00 ton

5 tons Sheet Steel @ \$95.00 ton
$\$ 730.00$

495.00

$\$ \underline{\$ 1,225.00}$

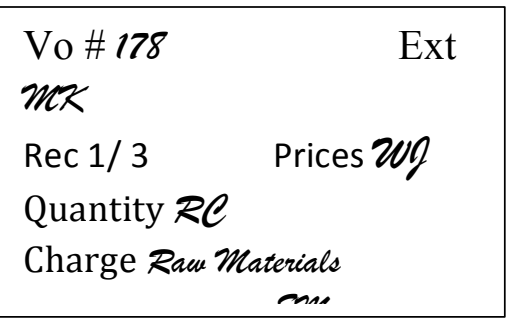




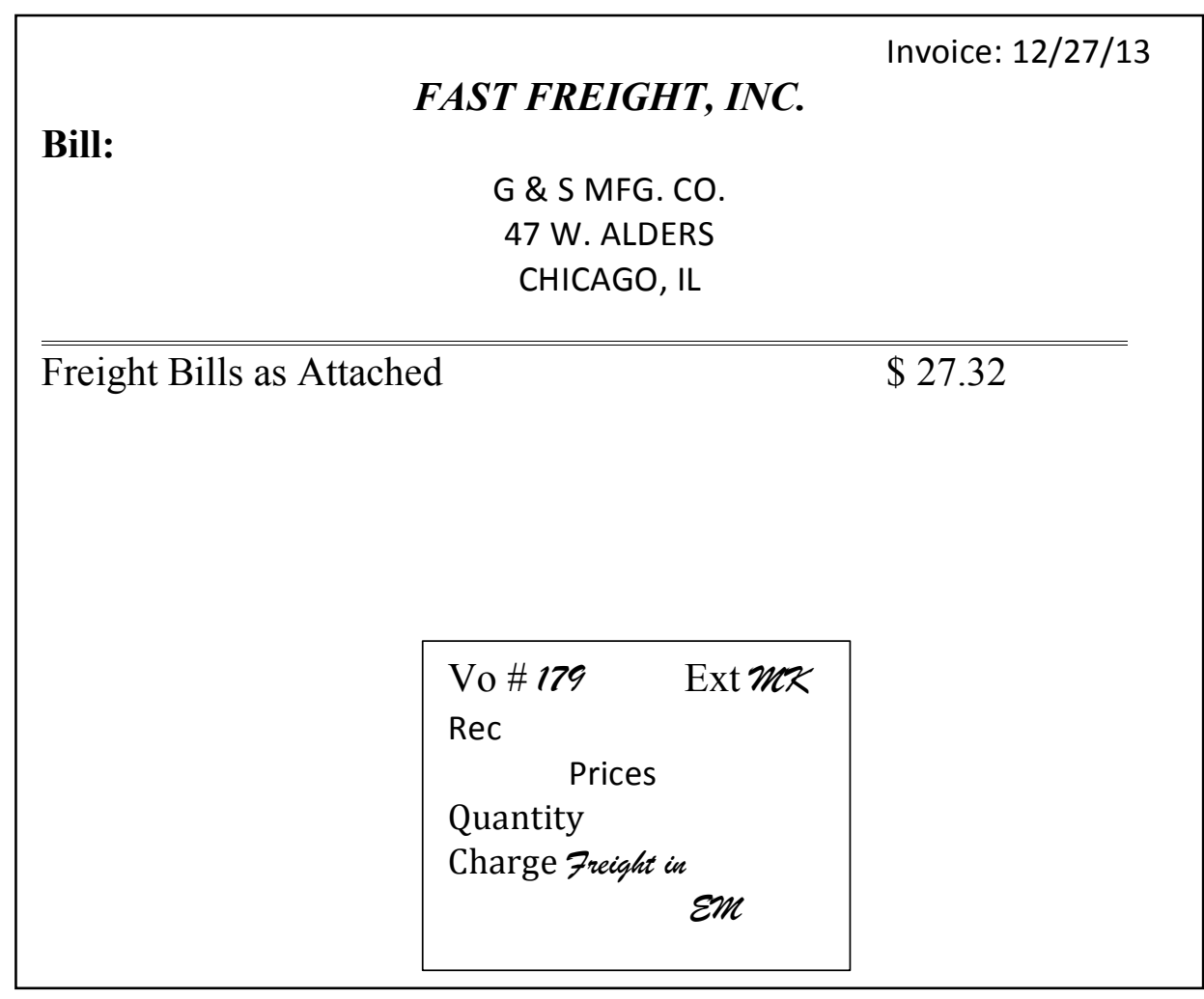

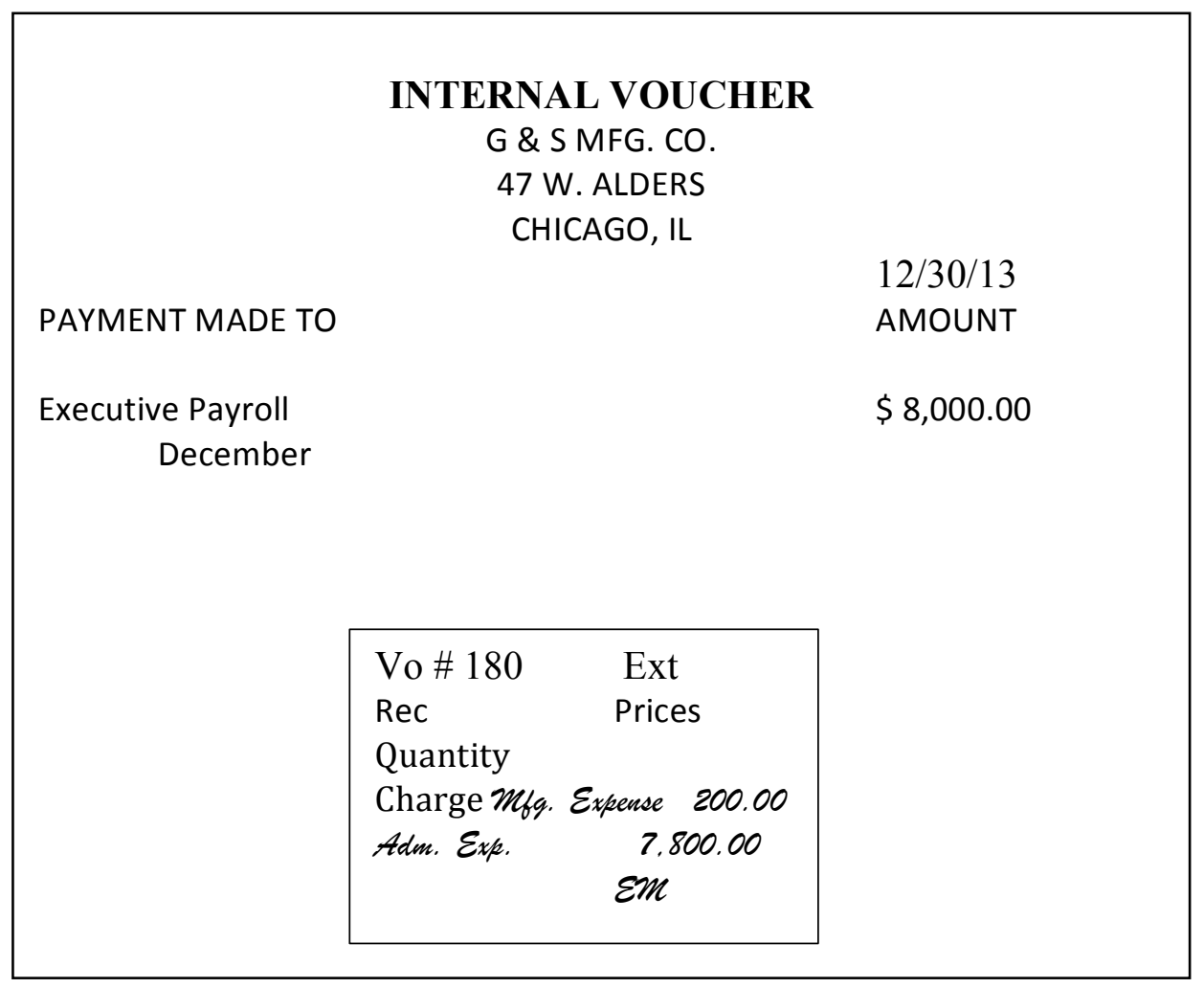




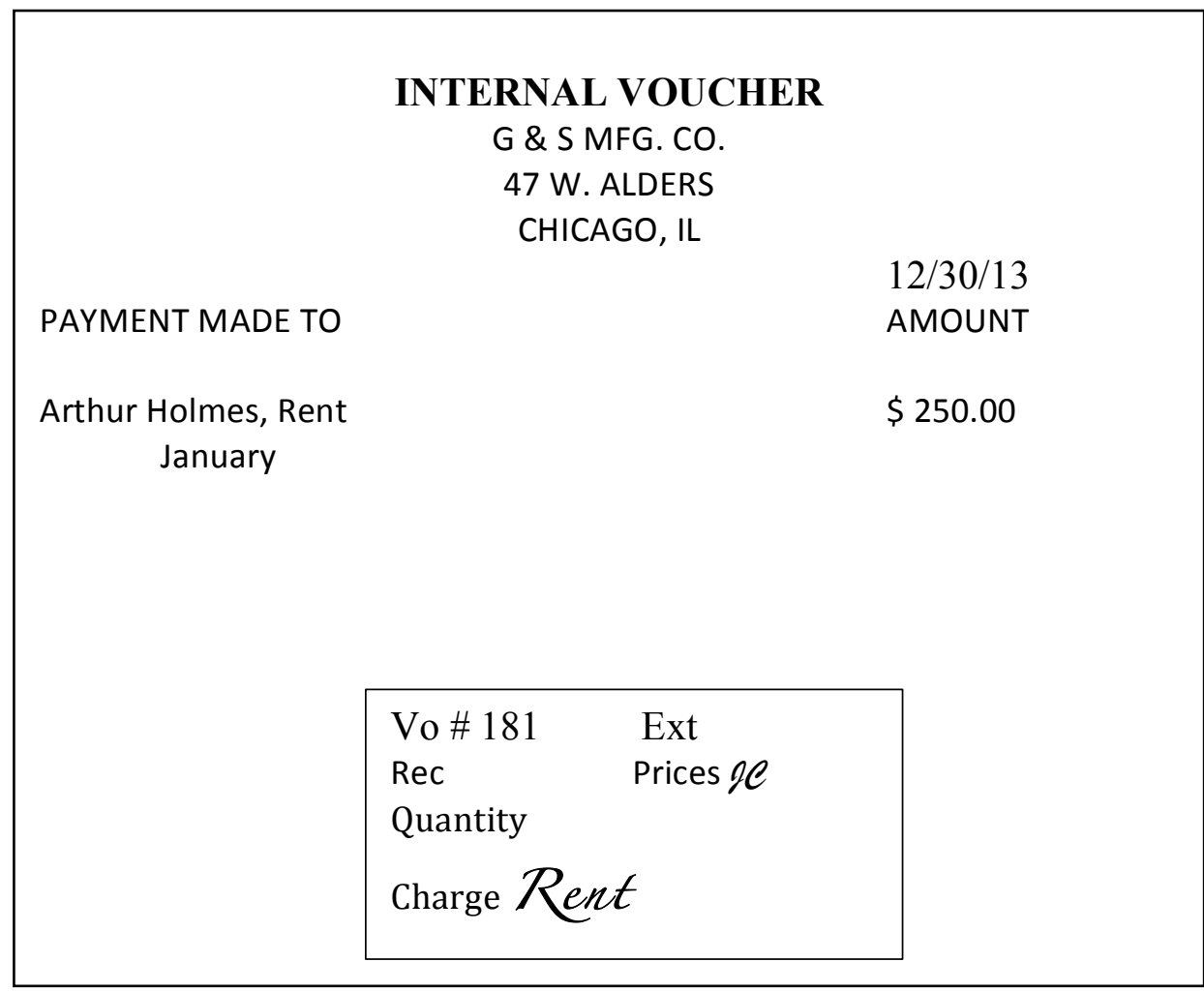

\section{HEILPERN IRON WORKS}

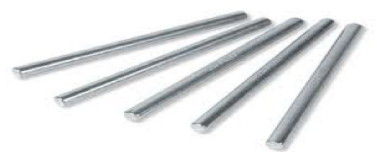

Invoice: $12 / 30 / 13$

SOLD TO:

G \& S MFG. CO.

47 W. ALDERS

CHICAGO, IL

Terms: $2 / 10$

20,000 LBS. Iron Bars $1 / 4$ in. @ 60.00 ton $\$ 600.00$

SHIP TO:

G \& S MFG. CO.

47 W. ALDERS

CHICAGO, IL

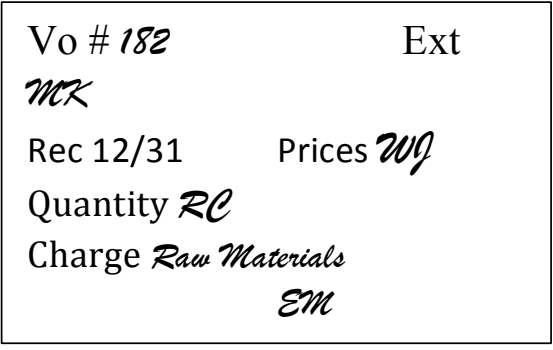




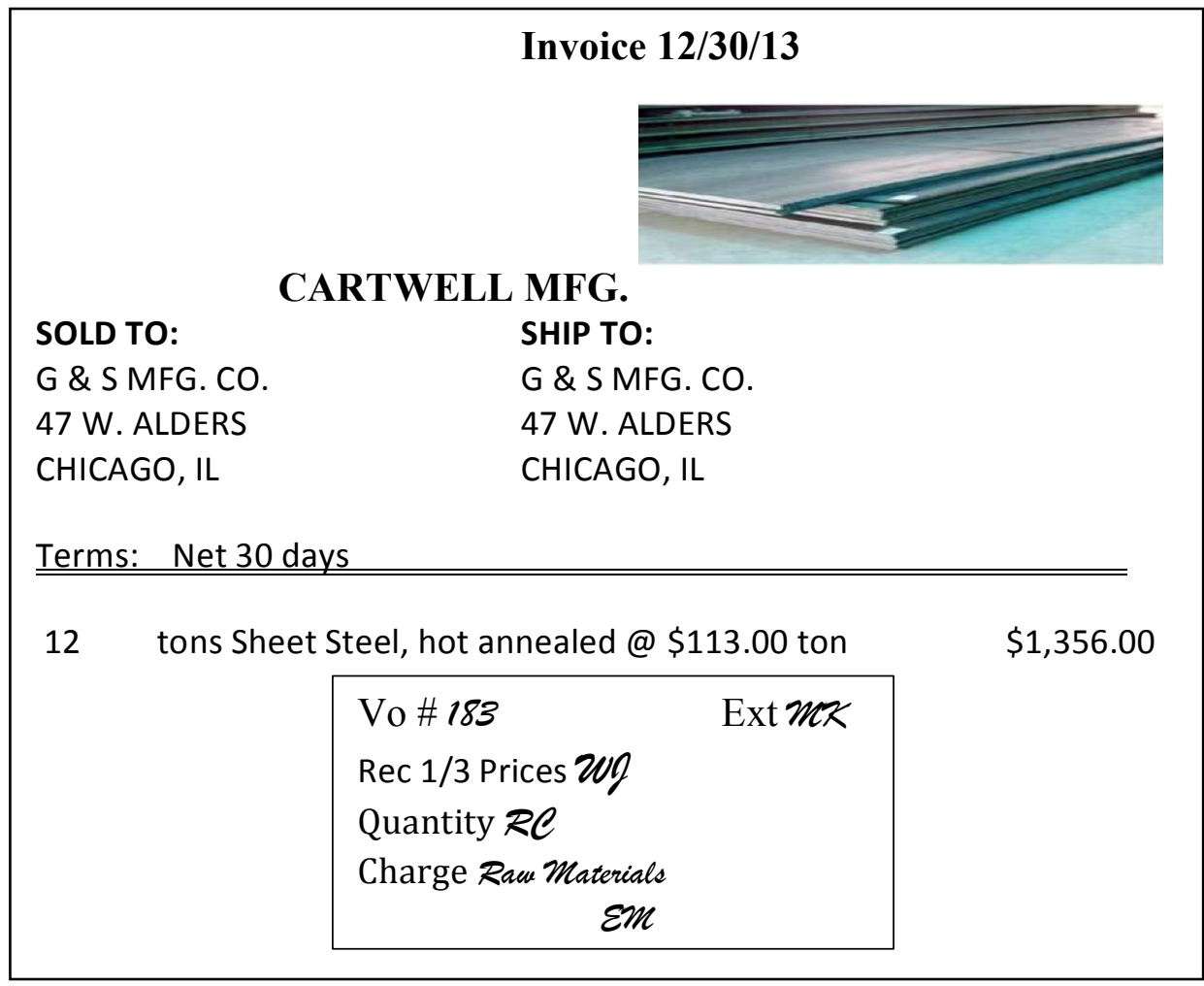

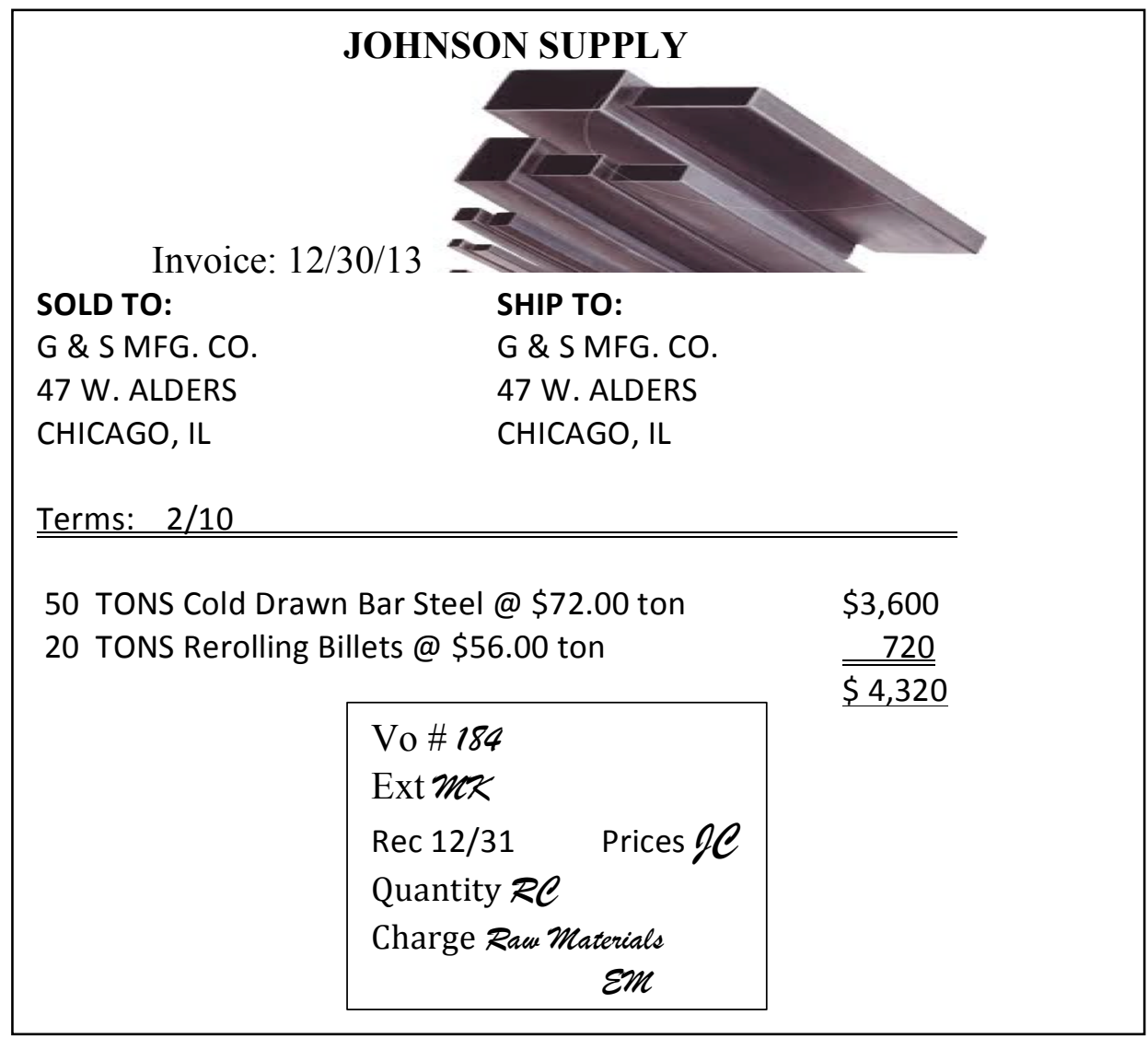

